\title{
HNRNPD wt Allele
}

National Cancer Institute

\section{Source}

National Cancer Institute. HNRNPD wt Allele. NCI Thesaurus. Code C102831.

Human HNRNPD wild-type allele is located in the vicinity of $4 q 21$ and is approximately 22

$\mathrm{kb}$ in length. This allele, which encodes heterogeneous nuclear ribonucleoprotein D0,

plays a role in the catabolism of RNA. 